\title{
JUURNAL_RU
}



COMPANY GROUP "INTELLEKT"

\author{
Селиверстова Ю.К. \\ Пермский филиала Финуниверситета \\ Пермь, Россия
}

doi: 10.18411//j2016-9-3-11

idsp 000001: lj2016-18-3-11

\section{Использование лексем с семантикой высокой степени звука в произведениях современных писателей}

При создании художественного литературного произведения автор воспроизводит реальную картину мира. Эта картина является комплексной, то есть состоит из целого спектра компонентов. Автор использует слова с семантикой цвета, вкуса, звука, запаха и т.д. В результате читатель получает возможность воспринимать созданную автором реальность во всей полноте.

В целом ряде статей мы анализировали степень использования современными писателями лексем с семантикой звука. В частности, нами был проведен анализ текста произведений Л. Улицкой «Зеленый шатер» и А. Чудакова «Ложится мгла на старые ступени...» Данные произведения имеют общую тему: авторами показана часть периода советской истории в аспекте тоталитаризма.

В результате анализа текста нами было выявлено 766 случаев использования лексем с семантикой звука в романе Л. Улицкой и 378 случаев в романе А. Чудакова, что является одинаковым в процентном соотношении относительно объема каждого произведения.

Каждый из авторов представил объемную звуковую картину мира советской действительности, используя определенные художественные приемы. Например, А. Чудаков использовал аллитерацию, градацию, Л. Улицкая отдавала предпочтение классическим приемам: многозвучие, антитеза и т.п.

Для удобства анализа все случаи использования слов с семантикой звука были классифицированы. Мы выделили группы в зависимости от силы звука, 
его интенсивности, а также насыщенности звуковой палитры и особенностей построения предложения, т.е. синтаксических особенностей. Выявленные группы представлены в Таблице 1.

Таблища 1

Количество вылвленных звуковых лексем по группам

\begin{tabular}{|c|c|c|c|c|}
\hline & \multicolumn{2}{|c|}{$\begin{array}{c}\text { Л. Улицкая } \\
\text { «Зеленый шатер» }\end{array}$} & $\begin{array}{c}\text { А. Чудаков «Ложится мгла на старые } \\
\text { ступени...» }\end{array}$ \\
\hline 1. Высокая степень звука & 494 случая & $64 \%$ & 263 случая & $69,5 \%$ \\
\hline 2. Низкая степень звука & 52 случая & $7 \%$ & 30 случаев & $8 \%$ \\
\hline $\begin{array}{c}\text { 3. Отсутствие звука } \\
\text { (тишина) }\end{array}$ & 76 случаев & $10 \%$ & 34 случая & $9 \%$ \\
\hline 4. Междометия & 9 случаев & $1 \%$ & 10 случаев & $3 \%$ \\
\hline 5. Многозвучие & 61 случай & $8 \%$ & 28 случаев & $7 \%$ \\
\hline б. Антитеза & 10 случаев & $1,5 \%$ & 8 случаев & $2 \%$ \\
\hline 7. Шипщие звуки & 65 случаев & $8,5 \%$ & 4 случая & $1 \%$ \\
\hline 8. Градация & нет случаев & & 1 случай & $0,5 \%$ \\
\hline Итог & 767 случаев & 378 случаев \\
\hline
\end{tabular}

В данной статье мы остановимся на подробном анализе самой многочисленной группы 1 - слова с семантикой высокой степени звука применительно к тексту каждого произведения. В тексте произведения Л. Улицкой было выявлено 494 случая употребления подобных лексем, что составляет $64 \%$ от общего количества случаев употребления слов со звуковой семантикой, в тексте произведения А. Чудакова было выявлено 263 случая, что составило 69,5\% от общего количества.

Каждая выявленная фраза содержала слово-ядро, т.е. слово-носитель семантики звука. Авторы использовали возможности различных частей речи вплоть до употребления слов-междометий для передачи звуковой картины мира. В результате мы проанализировали каждое слово с семантикой высокой степени звука на предмет принадлежности его к определенной части речи. Итоги анализа представлены в Таблице 2.

Таблица 2

Количество выявленных звуковых лексем с семантикой высокой степени звука с точки зрения морфологической принадлежности

\begin{tabular}{|c|c|c|c|c|}
\hline & \multicolumn{2}{|c|}{$\begin{array}{c}\text { Л. Улицкая } \\
\text { «Зеленый шатер» }\end{array}$} & $\begin{array}{c}\text { А. Чудаков «Ложится мгла на старые } \\
\text { ступени...» }\end{array}$ \\
\hline 1. Имя существительное & 169 случаев & $34 \%$ & 52 случая & $20 \%$ \\
\hline 2. Глагол & 318 случаев & $64 \%$ & 204 случая & $77,5 \%$ \\
\hline 3. Имя прилагательное & 3 случая & $0,8 \%$ & 2 случая & $0,7 \%$ \\
\hline 4. Наречие & 2 случая & $0,6 \%$ & 4 случая & $1,5 \%$ \\
\hline 5. Причастие & 1 случай & $0,3 \%$ & нет случаев & \\
\hline 6. Деепричастие & 1 случай & $0,3 \%$ & нет случаев & $0,3 \%$ \\
\hline $\begin{array}{l}\text { 7. Сравнительная } \\
\text { стенень наречия }\end{array}$ & нет случаев & & 1 случай & 263 случая \\
\hline \multicolumn{2}{|c|}{ Итог } & \multicolumn{2}{|c|}{} \\
\hline
\end{tabular}


Из данных, представленных в Таблице 2, видно, что каждый из выбранных авторов использует глаголы как основной инструмент воспроизведения звуковой картины мира: $64 \%$ в тексте романа Л.Улицкой, 77,5\% в тексте романа А. Чудакова. А. Чудаков отдает предпочтение глаголам в большей степени, чем Л. Улицкая. Нам кажется это обоснованным в связи с морфологическими особенностями глагола, который обозначает действие. Также выявлены случаи использования отглагольных частей речи - причастия и деепричастия со звуковой семантикой в тексте произведения Л. Улицкой. Кроме того, А. Чудаков использует даже сравнительную степень наречия для отражения усиления силы звука.

На втором месте по частоте использования в текстах произведений обоих авторов с большим процентным отрывом от других частей речи оказались имена существительные, которые обозначают предмет или явление: $34 \%$ в произведении Л. Улицкой, 20\% в произведении А. Чудакова. В данном случае Л. Улицкая использует больше имен существительных, чем А. Чудаков. Авторы использовали такие существительные, как «визг», «хохотанье», «щелчок» и другие.

Таким образом, при прочтении произведений Л. Улицкой и А. Чудакова мы можем наблюдать описание одной и той же эпохи глазами разных героев, прошедших свой жизненный путь в условиях советской действительности. Мы можем также утверждать, что авторы использовали разный набор звуковых лексем: случаев повторения одинаковых слов выявлено немного (распространенные слова: смеяться, плакать, голос, хохотать и др.). В основном набор звуковых лексем каждого автора индивидуален. Это позволило каждому из писателей создать свою, индивидуально-авторскую картину мира, представленную в произведении. Действие романа Л. Улицкой происходит в Москве, А. Чудакова - в небольшом казахстанском городке Чебачинске. Это также дает объяснение тому факту, что авторы использовали различные по значению слова. Улицкая чаще использует слова со значением шепота: в столице люди не выражали свои эмоции громко, опасаясьвысказывать свои мысли вслух. Но в то же время мы наблюдаем устойчивую тенденцию: оба автора активно используют глаголы и имена существительные. 
Каждый из авторов представил достаточно объемную звуковую картину мира советской действительности, т.е. читатель может полноценно вникнуть в содержание произведения, почувствовать описываемую эпоху.

\section{Литература:}

1. Улицкая Людмила Зеленый шатер [Электронный ресурс] Режим доступа: www.e-libra.ru

2. Александр Чудаков Ложится мгла на старые ступени [Электронный pecypc] Режим доступа: www.ModernLib.ru 